\title{
Pengukuran Variabel Makro dan Kinerja Keuangan terhadap Perubahan Harga Saham
}

\author{
Munawarah, S.E., M.Si \\ Medan, Indonesia \\ munawarah1710@yahoo.com
}

\author{
Jeffry Suryono, S.Ak \\ Medan, Indonesia \\ jeffrysuryono9@gmail.com
}

\begin{abstract}
The aim of this study was to investigate the effect of inflation rate, interest rate, and net profit on stock prices at Metal companies listed on the Indonesia Stock Exchange in 20112015. The independent variables of this research were the rate of inflation, interest rates, and net profit. Dependent variable of this research was stock price. The research used a quantitative method. The populations were 16 metal companies listed in Indonesia Stock Exchange and there were 15 companies used as sample which taken by purposive sampling technique. The research data were the company's financial statements at the Indonesia Stock Exchange. The data were analized by multiple linear regression analysis. The results of this research indicated that Simultaneously, the rate of inflation, interest rates, and net profit had a positive and significant effect on stock prices. And partially, the inflation rate did not have a significant effect on stock prices, the interest rate did not have a significant effect on the price shares and net profit had a positive and significant effect on stock prices. The value of $R$ square 0,289 shows that simultaneously the inflation rate, interest rate and net profit contributed to stock price only $28,9 \%$, and the remaining $71,11 \%$ were affected by other variables not included in this study.
\end{abstract}

Keywords: Inflation Rate, Interest Rate, Net Profit, Stock Price

\section{PENDAHULUAN}

Investasi merupakan salah satu bentuk cara untuk mendapatkan keuntungan yang dapat dikatakan dihasilkan dengan cukup cepat bila dilakukan dengan benar. Kegiatan ini memiliki berbagai macam pilihan alat investasi, seperti saham, obligasi, waran, right, obligasi konvertibel, dan berbagai produk turunan seperti opsi (put atau call). Salah satu alat investasi yang banyak mengundang ketertarikan berinvestasi adalah saham.

Sebagai bukti kepemilikan atau penyertaan modal, maka setiap individu memiliki hak di dalam suatu perusahaan terkait dengan kebijakan yang diterapkan. Investor harus mampu mencermati dinamika harga saham melalui informasi yang akurat mengenai kinerja keuangan perusahaan serta kondisi makro ekonomi dan informasi lainnya sehingga dapat membantu investor dalam memutuskan saham perusahaan yang layak dipilih. Kemampuan investor dalam memahami dan meramalkan kondisi ekonomi makro di masa datang akan sangat berguna dalam pembuatan keputusan investasi yang menguntungkan.Inflasi yang tidak stabil akan menciptakan ketidakpastian bagi pelaku ekonomi untuk mengambil keputusan berbisnis. Hal ini juga akan menyulitkan masyarakat untuk mengambil keputusan investasi, konsumsi, dan produksi yang pada akhirnya akan berpengaruh negatif terhadap harga saham itu sendiri. Inflasi yang tinggi akan membuat tingkat komsumsi menjadi berkurang sebab harga dari barang barang mengalami kenaikan, yang berakibat pada berkurangnya penjualan perusahaan sehingga mempengaruhi harga sahamnya. Keadaan inflasi yang cukup tinggi akan diikuti 
dengan naiknya suku bunga guna meredam tingginya inflasi. Jika suku bunga naik, maka beban perusahaan bertambah, terutama perusahaan yang banyak berutang dari bank. Beban yang semakin bertambah akan mengurangi tingkat keuntungan perusahaan, akibatnya harga saham perusahaan itu akan tertekan.

Selain variabel makro tersebut, kinerja keuangan juga dapat membantu memberikan keputusan bagi investor dalam investasi saham. Kinerja keuangan sebagai faktor fundamental memegang peranan penting karena mengandung data internal yang berkaitan dengan data keuangan, siklus keuangan, dan pangsa pasar perusahaan. Cara mengukurnya dapat dilihat dari kemampuan perusahaan dalam menghasilkan laba. Maju mundurnya sebuah perusahaan tergantung dari keuntungan yang diperoleh setiap tahun. Informasi tentang laba atau tingkat return yang diperoleh perusahaan yang tercermin dalam laporan keuangan akan menimbulkan reaksi terhadap harga saham perusahaan. Apabila laba yang diperoleh perusahaan tinggi, cenderung harga saham akan meningkat, sehingga banyak investor yang tertarik untuk menanamkan investasi di perusahaan. Sebaliknya, apabila laba yang diperoleh perusahaan rendah, maka harga saham cenderung akan menurun, sehingga akan menurunkan minat investor untuk menanamkan investasi diperusahaan.

Sebagai negara yang terus mengalami pembangunan terutama di bidang infrastruktur tentunya kebutuhan atas logam dan barangbarang metal seperti besi, baja, tembaga, aluminium, kuningan menjadi meningkat. Pembangunan yang meningkat tentunya mendorong geliat perusahaan di sektor logam terus bangkit. Investor dapat menangkap sinyal positif bahwa sektor ini memberikan keuntungan melalui akan banyaknya penjualan di sektor logam untuk memenuhi kebutuhan pembangunan sehingga penjualan tergolong tinggi dan dapat mendongkrak perolehan laba perusahaan sekaligus harga sahamnya. Investor tidak perlu kawatir karena sektor ini akan terus mengalami kemajuan sampai 5 tahun mendatang.

Berdasarkan uraian latar belakang dan fenomena yang telah dikemukakan, maka menjadi permasalahan dalam penelitian ini:

Apakah variabel makro seperti tingkat inflasi dan tingkat suku bunga, dan kinerja keuangan berpengaruh terhadap perubahan harga saham pada perusahaan logam dan sejenisnya yang terdaftar di BEI periode 2011-2015?

\section{TINJAUAN PUSTAKA}

Berbicara mengenai variabel makro ekonomi, maka tidak akan pernah terlepas dengan kebijakan moneter yang dilakukan pemerintah. Kebijakan moneter merupakan tindakan yang dilakukan oleh penguasa moneter untuk mempengaruhi jumlah uang beredar dan kredit yang pada gilirannya akan mempengaruhi kegiatan ekonomi masyarakat (Nopirin, 2012:140-141). Manurung (2009:7) berpendapat bahwa Kebijakan moneter mencakup manajemen tingkat bunga dan jumlah uang beredar. Kebijakan moneter bank sentral mempengaruhi tingkat suku bunga, inflasi, nilai tukar mata uang, siklus bisnis, penggunaan tenaga kerja, stabilitas lembaga keuangan, dan pertumbuhan ekonomi.

\section{a. Tingkat Inflasi}

Menurut Putong (2008:133), tingkat inflasi adalah proses kenaikan harga-harga unum secara terus-menerus. Akibat dari inflasi secara terus-menerus adalah menurunnya daya beli masyarakat karena secara riel tingkat pendapatannya juga menurun. Inflasi juga dapat dikatakan adanya kecenderungan harga-harga semua jenis barang naik secara terus menerus. Gilarso (2004:200) juga menambahkan bahwa inflasi dapat dirumuskan sebagai kenaikan harga umum yang bersumber pada terganggunya keseimbangan antara arus uang dan arus barang.

\section{b. Tingkat Suku Bunga}

Menurut Sukirno (2010:375), bunga yang dinyatakan sebagai persentasi dari modal dinamakan suku bunga. Umumnya persentasi 
yang dinyatakan menunjukkan suku bunga dari sejumlah modal di dalam satu tahun.

Kasmir (2012:40), didalam bukunya juga menyatakan bahwa tingkat bunga merupakan balas jasa yang diberikan oleh bank berdasarkan prinsip konvensional kepada nasabah yang membeli atau menjual produknya, tingkat bunga juga dapat diartikan sebagai harga yang harus di bayar kepada nasabah (yang memiliki simpanan) dengan harga yang harus dibayar oleh nasabah kepada bank (nasabah yang memperoleh pinjaman).

\section{c. Laba Bersih}

Menurut Kasmir (2012:303), laba bersih merupakan laba yang telah dikurangi biayabiaya yang merupakan beban perusahaan dalam suatu periode tertentu, termasuk pajak. Dalam menghitung laba bersih, dapat digunakan rumus menghitung laba sebelum pajak penghasilan dikurangi dengan pajak penghasilan,

\section{d. Harga Saham}

Saham merupakan tanda penyertaan modal seseorang atau badan didalam suatu perusahaan. Adanya penyertaan tersebut, maka pihak penyetor modal dapat memiliki klaim atas pendapatan perusahaan, klaim atas asset perusahaan serta hak untuk memberikan suara pada saat RUPS. Saham suatu perusahaan dikatakan baik jika memliki trend kenaikan harga saham. Menurut Sartono (2010:9), harga saham itu terbentuk dipasar modal dan ditentukan oleh beberapa faktor seperti laba per saham atau earning per share (EPS), rasio laba terhadap harga per lembar saham atau price earning ratio (PER), tingkat bunga bebas resiko yang diukur dari tingkat bunga deposito pemerintah dan tingkat kepastian operasi perusahaan.

$$
\text { Menurut Darmadji (2012:10), }
$$
pembentukan harga saham terjadi karena adanya permintaan dan penawaran atas saham tersebut. Dengan kata lain harga saham terbentuk oleh penawaran (supply) dan permintaan (demand) atas saham tersebut.

\section{e. Kerangka Konseptual dan Pengembangan Hipotesis}

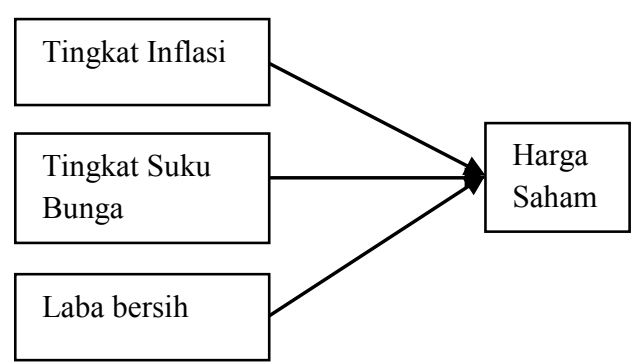

\section{Gambar 1. Kerangka Konsep}

Inflasi yang tinggi akan menjatuhkan harga saham di pasar. Inflasi yang rendah akan berakibat pertumbuhan ekonomi yang sangat lamban, yang pada akhirnya mengakibatkan harga saham bergerak secara lamban pula (Samsul, 2015:211). Menurunnya daya beli masyarakat sebagai akibat dari kenaikan harga barang-barang secara umum, sehingga pada akhirnya perusahaan akan kesulitan dalam berproduksi karena biaya produksi menjadi tinggi dan harga jualnya tidak terjangkau oleh konsumen, sehingga penjualannya akan turun dan akhirnya harga saham perusahaan tersebut melemah.

$\mathrm{H}_{1}$ : Tingkat Inflasi berpengaruh terhadap Harga Saham pada perusahaan logam dan sejenisnya yang terdaftar di BEI periode 2011-2015.

Kenaikan tingkat suku bunga pinjaman ataupun bunga deposito berdampak turunnya harga saham. Sebaliknya, penurunan tingkat bunga pinjaman maupun tingkat bunga deposito akan menaikkan harga saham di pasar (Samsul, 2015:211). Maka dapat disimpulkan bahwa hubungan antara harga saham dengan tingkat bunga pasar adalah berbanding terbalik. Semakin besar tingkat suku bunga pasar maka akan semakin kecil harga dari saham.

$\mathrm{H}_{2}$ : Tingkat Suku Bunga berpengaruh terhadap Harga Saham pada perusahaan logam dan sejenisnya yang terdaftar di BEI periode 2011-2015.

Fundamental perusahaan merupakan 
kondisi yang berhubungan langsung dengan kinerja perusahaan. Kinerja keuangan suatu perusahaan dikatakan baik jika perusahaan tersebut menghasilkan laba yang cukup besar dan konstan. Biasanya harga sahamnya akan semakin meningkat. Sebaliknya, bila suatu perusahaan mempunyai kinerja yang buruk dan selalu menderita kerugian, maka otomatis sahamnya juga akan dijauhi oleh para investor sehingga harga sahamnya akan semakin menurun (Siswoyo (2013:36)). Dapat disimpulkan bahwa laba merupakan prediktor aliran kas ke investor yang menunjukkan kinerja suatu perusahaan apakah perusahaan tersebut mendapatkan peningkatanatau penurunan laba atau bahkan mengalami kerugian yang akan mempengaruhi harga saham perusahaan tersebut.

$\mathrm{H}_{3}$ : Laba Bersih berpengaruh terhadap Harga Saham pada perusahaan logam dan sejenisnya yang terdaftar di BEI periode 2011-2015.

\section{METODE PENELITIAN}

Penelitian ini menggunakan data sekunder yang bersumber dari laporan keuangan perusahaan yang berada di sektor logam dan sejenisanya yang terdaftar di Bursa Efek periode 2011-2015 yang dapat diunduh melalui website www. idx.co.id. Populasi yang digunakan dalam penelitian ini adalah perusahaan logam dan sejenisnya yang terdaftar di Bursa Efek Indonesia dengan jumlah 16 perusahaan pada periode 2011-2015. Pengambilan sampel dilakukan dengan teknik purposive sampling yaitu penentuan sampel yang sesuai dengan kriteria penelitian. Adapun kriteria yang dijadikan sampel dalam penelitian ini adalah sebagai berikut :

1. Perusahaan logam dan sejenisnya yang terdaftar di Bursa Efek Indonesia periode 2011-2015.

2. Perusahaan logam dan sejenisnya yang terdaftar di Bursa Efek Indonesia yang mempublikasikan laporan keuangan dengan lengkap dan berturut-turut periode 20112015.

Dari penentuan kriteria, hanya satu yang tidak lulus dari kriteria, sehingga jumlahsampel yang digunakan yaitu 15 sampel dengan periode pengamatan 5 tahun. Total pengamatan menjadi $15 \times 5=75$ perusahaan.

Adapun defenisi operasional variabel penelitian adalah sebagai berikut :

a. Tingkat Inflasi merupakan Proses kenaikan harga-harga umum secara terusmenerus.Yang menyebabkan menurunnya daya beli masyarakat (Putong , 2008:133). Rumus :

$$
\mathrm{Inf}=\frac{\mathrm{IHK} \mathrm{n}-\mathrm{HHK} \mathrm{n}-1}{\mathrm{IHK} \mathrm{n}-1} \times 100 \%
$$

b. Tingkat Suku Bunga adalah sejumlah uang yang dibayarkan oleh pihak satu atas penggunaan dana milik pihak lain selama periode tertentu (Joesoef, 2008:41). Rumus:

Tingkat Suku Bunga $=$ BI Rate

c. Laba Bersih merupakan laba sebelum pajak penghasilan dikurangkan dengan pajak penghasilan akan diperoleh laba atau rugi bersih (Hery , 2015:50). Rumus :

$\mathrm{EAT}=$ Laba sebelum pajak - pajak penghasilan

d. Harga Saham terbentuk dipasar bursa tertentu yang dilakukan oleh pelaku pasar dan ditentukan oleh permintaan dan penawaran saham yang bersangkutan di pasar modal (Hartono, 2008:167). Rumus : Harga Saham $=$ Harga Saham Penutupan (Closing Price)

\section{HASIL PENELITIAN DAN PEMBAHASAN}

Tabel 4.1 Statistik Deskriptif

\begin{tabular}{|l|c|l|l|l|l|}
\hline & $\mathrm{N}$ & \multicolumn{1}{|c|}{ Min } & \multicolumn{1}{|c|}{ Max } & \multicolumn{1}{|c|}{ Mean } & Std. Dev \\
\hline Tk_Inflasi & 75 & .043 & .070 & .05900 & .009572 \\
Tk_Sk_ & 75 & .058 & .075 & .06780 & .006537 \\
Bunga & & & & & \\
Laba_Bersih & 75 & $-4 . E 12$ & $1 . E 12$ & $-3.99 \mathrm{E} 10$ & $5.792 \mathrm{E} 11$ \\
Harga_Saham & 75 & 61.00 & 13283.33 & 1271.580 & 2499.8328 \\
ValidN & 75 & & & & \\
(listwise) & & & & & \\
\hline
\end{tabular}

Sumber : Hasil Pengolahan Data, 2018

Rata-rata Tingkat Inflasi adalah 0,059 dengan standar deviasi 0,009572. Nilai 
minimumnya 0,043 , dan nilai maksimum 0,07 . Rata-rata Tingkat Suku Bunga adalah 0,0678 dengan standar deviasi 0,006537. Nilai minimum 0, dan nilai maksimum 0, 75. Ratarata Laba Bersih adalah -3.99E10 dengan standar deviasi 5.792E11. Nilai minimum -4.E12 dan nilai maksimum 1.E12 . Rata-rata Harga Saham adalah 1271,58 dengan standar deviasi 2499,83283. Nilai minimum 61 dan nilai maksimum 13283,33

\section{A.Hasil Uji Asumsi Klasik}

\section{Uji Normalitas}

Uji normalitas dilakukan dengan uji statistik Kolmogorov Smirnov. Diperoleh hasil, nilai Signifikansi berada dibawah 0,05, dan menyalahi asumsi klasik, sehingga dilakukan transformasi data melalui Logaritma natural. Jumlah observasi menjadi berkurang dari 75 perusahaan menjadi 51 perusahaan.

Tabel 4.2 Uji Kolgomorov-Smirnov Setelah Transformasi

\begin{tabular}{|ll|r|}
\hline & & $\begin{array}{l}\text { Unstandardized } \\
\text { Residual }\end{array}$ \\
& & 51 \\
& $\mathrm{~N}$ & .0000000 \\
Normal & Mean \\
Parameters ${ }^{\mathrm{a}, \mathrm{b}}$ & Std. Deviation & 1.19413941 \\
Most Extreme & Absolute & .069 \\
Differences & Positive & .069 \\
& Negative & -.050 \\
& Kolmogorov-Smirnov Z & .495 \\
& Asymp. Sig. (2-tailed) & .967 \\
\hline
\end{tabular}

Sumber : Hasil Pengolahan Data, 2018

Hasil uji normalitas Kolmogorov Smirnov menunjukkan nilai signifikan 0,967 冈 0,05 dengan demikian dari hasil uji normalitas Kolmogorov Smirnov dapat diambil kesimpulan data telah berdistribusi normal.

\section{Uji Multikolinieritas}

Tabel 4.2 Uji Multikolinieritas

\begin{tabular}{|lc|c|c|}
\hline \multirow{2}{*}{ Model } & \multicolumn{2}{|c|}{ Collinearity Statistics } \\
\cline { 2 - 4 } & Tolerance & VIF \\
\hline $1 \quad$ Ln_Tk_Inflasi & .448 & 2.230 \\
& Ln_Tk_Sk_Bunga & .447 & 2.239 \\
& & & \\
Ln_Laba_Bersih & .986 & 1.014 \\
\hline
\end{tabular}

Sumber : Hasil Pengolahan Data, 2018

Nilai tolerance variabel Tingkat Inflasi, Tingkat Suku Bunga, dan Laba Bersih berada diatas 0,10 . Hal ini didukung pula dengan nilai VIF kseseluruhan variabel lebih kecil dari 10. Kesimpulan yang diperoleh adalah model regresi terbebas dari multikolonieritas

\section{Uji Autokorelasi}

Tabel 4.5 Uji Autokorelasi

\begin{tabular}{|l|l|l|l|l|l|}
\hline Model & $\mathrm{R}$ & $\begin{array}{l}\mathrm{R} \\
\text { Square }\end{array}$ & $\begin{array}{l}\text { Adjuste } \\
\mathrm{d} \quad \mathrm{R} \text { Ruare }\end{array}$ & $\begin{array}{l}\text { Std. Error } \\
\text { of the } \\
\text { Estimate }\end{array}$ & $\begin{array}{l}\text { Durbin- } \\
\text { Watson }\end{array}$ \\
\hline 1 & $.538^{\mathrm{a}}$ & .289 & .244 & 1.23166 & 1.766 \\
\hline
\end{tabular}

Sumber : Hasil Pengolahan Data, 2018

Durbin-Watson menunjukkan nilai $\mathrm{d}_{\mathrm{u}} \mathrm{\nabla}$

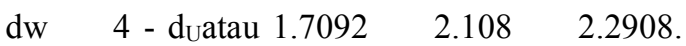
dapat disimpulkan tidak terdapat autokolerasi positif atau negatif pada model regresi.

\section{Uji Heterokedastisitas} Tabel 4.6 Uji Glejser

\begin{tabular}{|c|c|c|c|c|c|}
\hline \multirow[b]{2}{*}{ Model } & \multicolumn{2}{|c|}{$\begin{array}{l}\text { Unstandardize } \\
\text { d Coefficients }\end{array}$} & \multirow{2}{*}{$\begin{array}{c}\begin{array}{c}\text { Std } \\
\text { Coeffici } \\
\text { ents }\end{array} \\
\text { Beta }\end{array}$} & \multirow[b]{2}{*}{$\mathrm{t}$} & \multirow[b]{2}{*}{ Sig } \\
\hline & $\mathrm{B}$ & $\begin{array}{l}\text { Std. } \\
\text { Error }\end{array}$ & & & \\
\hline 1 (Constant) & .484 & 3.208 & & .151 & .881 \\
\hline Ln_Tk_Inflasi & .758 & .811 & .194 & .935 & .355 \\
\hline $\begin{array}{l}\text { Ln_Tk_Sk_Bun } \\
\text { ga }\end{array}$ & .139 & 1.526 & .019 & .091 & .928 \\
\hline Ln_Laba_Bersih & .126 & .073 & .240 & 1.717 & .092 \\
\hline
\end{tabular}

Sumber : Hasil Pengolahan Data, 2018 
Hasil Uji Glejser menunjukkan nilai signifikansi masing-masing variabel $>0,05$, sehingga dapat disimpulkan variabel terbebas dari gejala heteroskedastisitas.

\section{B. Uji Hipotesis}

1. Koefisien Determinasi

Tabel 4.7 Uji Koefisien Determinasi

\begin{tabular}{|l|l|l|l|l|l|}
\hline $\begin{array}{l}\text { Mode } \\
1\end{array}$ & $\mathrm{R}$ & $\begin{array}{l}\mathrm{R} \\
\text { Square }\end{array}$ & $\begin{array}{l}\text { Adjuste } \\
\mathrm{d} \quad \mathrm{R} \\
\text { Square }\end{array}$ & $\begin{array}{l}\text { Std. Error of } \\
\text { the Estimate }\end{array}$ & $\begin{array}{l}\text { Durbin- } \\
\text { Watson }\end{array}$ \\
\hline 1 & $.538^{\mathrm{a}}$ & .289 & .244 & 1.23166 & 1.766 \\
\hline
\end{tabular}

Sumber : Hasil Pengolahan Data, 2018

Besarnya nilai $R^{2}$ adalah 0.289 . Hal ini menunjukkan bahwa 28,9 \% variasi variabel Harga Saham dapat dijelaskan oleh variasi variabel Tingkat Inflasi, Tingkat Suku Bunga dan Laba Bersih, sedangkan sisanya sebesar $71,1 \%$ merupakan variasi variabel lain yang tidak dijelaskan dalam penelitian ini.

\section{Uji Simultan (Uji F)}

Tabel 4.8 Uji F

\begin{tabular}{|c|c|c|c|c|c|}
\hline Model & $\begin{array}{l}\text { Sum of } \\
\text { Squares }\end{array}$ & df & $\begin{array}{l}\text { Mean } \\
\text { Square }\end{array}$ & $F$ & Sig. \\
\hline 1 Regression & 29.044 & 3 & 9.681 & 6.382 & $.001^{\mathrm{a}}$ \\
\hline Residual & 71.298 & 47 & 1.517 & & \\
\hline Total & 100.342 & 50 & & & \\
\hline
\end{tabular}

Sumber : Hasil Pengolahan Data, 2018

Nilai $F_{\text {hitung }}$ sebesar 6.382 dan nilai $\mathrm{F}_{\text {tabel }}$ sebesar 2.8. Maka hasilnya adalah $F_{\text {hitung }}>F_{\text {tabel }}(6.382>2.8)$ dengan tingkat signifikan 0.001 (lebih kecil dari 0.05). Secara simultan keseluruhan variabel bebas berpengaruh terhadap Harga saham.

\section{Uji Parsial (Uji t)}

\begin{tabular}{|c|c|c|c|c|c|}
\hline \multirow[b]{2}{*}{ Model } & \multicolumn{2}{|c|}{$\begin{array}{l}\text { Unstandardized } \\
\text { Coefficients }\end{array}$} & \multirow{2}{*}{\begin{tabular}{|c}
$\begin{array}{c}\text { Standard } \\
\text { ized } \\
\text { Coeffici } \\
\text { ents }\end{array}$ \\
Beta
\end{tabular}} & \multirow[b]{2}{*}{$\mathrm{t}$} & \multirow[b]{2}{*}{ Sig } \\
\hline & B & $\begin{array}{l}\text { Std. } \\
\text { Error }\end{array}$ & & & \\
\hline 1 (Constant) & .700 & 5.702 & & .123 & .903 \\
\hline Ln_Tk_Inflasi & .183 & 1.442 & .023 & .127 & .899 \\
\hline $\begin{array}{l}\text { Ln_Tk_Sk_Bu } \\
\text { nga }\end{array}$ & 2.596 & 2.712 & .176 & .957 & .343 \\
\hline$\underset{h}{\text { Ln_Laba_Bersi }}$ & .553 & .130 & .525 & 4.241 & .000 \\
\hline
\end{tabular}

Sumber : Hasil Pengolahan Data, 2018

Berdasarkan tabel Uji Parsial diperoleh hanya variabel Laba bersih yang memiliki pengaruh da positif terhadap harga saham perusahaan Logam dan Sejenisnya.

Dari tabel diatas juga dapat diperoleh persamaan regresi linier berganda adalah sebagai berikut:

LN Harga Saham $=0.7+0.183$ LN Tk Inflasi +2.596 LN Tk SK Bunga +0.553 LN Laba Bersih

\section{Pembahasan}

Tingkat Inflasi sebesar $0.127<2,01174$ dengan nilai signifikan sebesar 0.899>0,05, maka disimpulkan Tingkat Inflasi tidak berpengaruh dan tidak signifikan terhadap Harga Saham. Hasil penelitian ini bertolak belakang dengan pendapat Samsul (2015) yang menyatakan inflasi yang tinggi akan menjatuhkan harga saham di pasar. Hal ini dapat disebabkan karena investor yang menanamkan modalnya dalam bentuk saham di Perusahaan logam dan Sejenisnya dianggap sebagai individu yang tercukupi secara finansial, atau termasuk sebagai tipe investor yang risk taker, sehingga terjadinya inflasi tidak terlalu berpengaruh dengan harga saham di pasar modal. Maka permintaan terhadap saham tetap stabil meskipun inflasi tetap meningkat. Hasil penelitian ini sejalan dengan penelitian Rohmanda, dkk (2014). 
Variabel Tingkat Suku Bunga, nilai $\mathrm{t}$ hitung 0,957 lebih kecil daripada $t$ tabel 2,01174 dengan nilai signifikan $0,343>0,05$. Maka dapat disimpulkan Tingkat Suku Bunga tidak berpengaruh dan tidak signifikan terhadap Harga Saham pada perusahaan Logam dan Sejenisnya. Hal ini disebabkan pergerakan dari Tingkat Suku Bunga tidak terlalu signifikan sehingga kurang menarik minat investor dalam menabung uangnya di bank, mereka masih lebih tertarik berinvestasi saham karena profit yang lebih menguntungkan dibandingkan dengan menabung uang mereka di bank. Dengan permintaan harga saham yang cukup stabil, maka harga saham itu sendiri tidak akan terpengaruhi dengan fluktuasi tingkat suku bunga. Hasil penelitian ini tidak sejalan dengan pendapat Kodrat (2010:283) bahwa hubungan antara harga saham seharusnya (nilai intrinsik) dengan tingkat bunga pasar (rm) adalah negative. Hasil penelitian juga bertentangan dengan hasil penelitian Amperaningrum \& Agung (2011) yang secara parsial tidak berpengaruh signifikan terhadap Harga Saham.

Nilai t hitung Laba Bersih sebesar 4.241 dengan nilai signifikan sebesar $0.000<0,05$. Nilai $\mathrm{t}$ hitung $>\mathrm{t}$ tabel atau $4.241>2.01174$ maka disimpulkan Laba Bersih berpengaruh positif dan signifikan terhadap Harga Saham pada perusahaan Logam dan Sejenisnya. Jika laba bersih mengalami peningkatan, maka akan diikuti dengan Harga Saham. Bila suatu perusahaan memperoleh laba, maka perusahaan tersebut cenderung mempunyai kesan yang baik untuk menjadi wadah investasi bagi para investor, karena apabila perusahaan mengalami laba maka investor juga akan mendapatkan pembagian keuntungan dari investasi yang dilakukan dalam bentuk saham. Hal ini juga mendukung pendapat Siswoyo (2013:36), yang menyatakan kinerja suatu perusahaan dikatakan baik jika perusahaan tersebut menghasilkan laba yang cukup besar dan konstan. Biasanya harga sahamnya akan semakin meningkat. Penelitian ini juga sejalan dengan hasil penelitian Hermansyah, dan Ariesanti (2008).

\section{KESIMPULAN DAN SARAN}

\section{a. Kesimpulan}

Berdasarkan pada hasil penelitian, maka dapat ditarik kesimpulan sebagai berikut:

1. Secara parsial, hanya variabel Laba Bersih yang berpengaruh terhadap Harga Saham Perusahaan Logam dan Sejenisnya, sementara variabel lainnya seperti Tingkat Inflasi, dan Tingkat Suku Bunga tidak berpengaruh terhadap Harga Saham .

2. Secara Simultan Tingkat Inflasi, Tingkat Suku Bunga, dan Laba Bersih berpengaruh positif dan signifikan terhadap Harga Saham pada perusahan Logam dan Sejenisnya.

3. Tingkat Inflasi, Tingkat Suku Bunga, dan Laba Bersih secara koefisien determinasi berpengaruh sebesar $28,9 \%$ terhadap variasi variabel Harga Saham (Y) sedangkan sisanya sebesar $71,1 \%$ merupakan variasi variabel lain yang tidak dijelaskan dalam penelitian ini. Hal ini berarti variabel makro yang dipilih melalui tingkat suku bunga dan tingkat inflasi tidak mampu menjelaskan pengaruhnya terhadap harga saham, sebaliknya hanya kinerja keuangan perusahaan sebagai faktor internal yang banyak mempengaruhi harga saham yang beredar di bursa efek.

\section{b. Saran}

Berdasarkan hasil analisis yang telah dilakukan, beberapa saran yang dianjurkan dari penelitian ini adalah :

1. Untuk manajemen perusahaan Logam dan Sejenisnya diharapkan meningkatkan kinerja perusahaan khususnya dalam kemampuan memperoleh laba, hal ini dimaksud agar saham perusahaan mengalami penigkatan secara signifikan agar dapat memberikan nilai tambah atau keuntungan bagi para pemegang saham dan calon investasi.

2. Untuk para pemegang saham dan calon investor sebaiknya melakukan penelaahan lebih lanjut atas resiko investasi dalam melakukan investasi pada saham perusahaan Logam dan Sejenisnya yang terdaftar di BEI. 
3. Untuk peneliti selanjutnya disarankan menggunakan variabel yang lebih luas, misalnya kurs mata uang untuk memperoleh hasil penelitian yang lebih luas terhadap harga saham pada perusahan logam dan sejenisnya yang terdaftar di BEI.

\section{DAFTAR PUSTAKA}

Amperaningrum, Izzati \& Robby Suryawan Agung. 2011. Pengaruh Tingkat Suku Bunga SBI, Nilai Tukar Mata Uang dan Tingkat Inflasi terhadap Perubahan Harga Saham Sub Sektor Perbankan Di Bursa Efek Indonesia. Universitas Gunadama :Jurnal Ekonomi Gunadama, Vol. 4

Darmadji, Tjiptono \& Hendry M.Fakhruddin. 2012. Pasar Modal di Indonesia. Jakarta: Salemba Empat.

Gilarso, T. 2004. Pengantar Ilmu Ekonomi Makro. Yogyakarta: Kanisius.

Hartono, Jogiyanto. 2008. Teori Portofolio dan Analisis Investasi. Edisi Kelima. BPFE. Yogyakarta.

Hermansyah, Iwan \& Eva Ariesanti. 2008. Pengaruh Laba Bersih Terhadap Harga Saham (Sensus Pada Perusahaan Food and Beverage Yang Terdaftar di Bursa Efek Jakarta). Universitas Siliwangi Tasikmalaya: Jurnal Akuntansi FE Unsil, Vol. 3, No. 1.

Hery. 2015. Analisis Laporan Keuangan Pendekatan Rasio Keuangan. Yogyakarta: CAPS (Center for Academic Publishing Service).

Joesoef, Jose. 2008.Pasar Uang \& Pasar Valuta Asing. Jakarta: Salemba Empat.

Kodrat, David \& Kurniawan Indonanjaya. 2010.Manajemen Investasi Pendekatan Teknikal \& Fundamental Untuk Analisis Saham. Yogyakarta: Graha Ilmu.
Kasmir. 2012. Analisis Laporan Keuangan. Jakarta: PT. Rajagrafindo Persada.

Manurung, J., dan Manurung, A.H. 2009. Ekonomi Keuangan dan Kebijakan Moneter. Jakarta: Salemba Empat.

Nopirin. 2012. Pengantar Ilmu Ekonomi MikroMakro. Yogyakarta: BPFE Yogyakarta.

Putong, Iskandar \& ND Andjaswati. 2008. Pengantar Ekonomi Makro. Jakarta: Mitra Wacana Media.

Rohmanda.,etc. 2014. Pengaruh Kurs Rupiah, Inflasi dan BI Rate Terhadap Harga Saham (Studi pada Indeks Sektoral Bursa Efek Indonesia Periode 2005-2013). Universitas Brawijaya Malang: Jurnal Administrasi Bisnis, Vol. 13, No. 1.

Samsul, Mohamad. 2015. Pasar Modal \& Manajemen Portofolio, Ed. 2. Jakarta: Salemba Empat.

Sartono, Agus. 2012. Manajemen Keuangan Teori dan Aplikasi, Edisi empat. Penerbit BPFE Yogyakarta.

Siswoyo, Sony. 2013. Analisis Fundamental \& Teknikal Untuk Profit Lebih Optimal. Jakarta: Gramedia Pustaka Utama.

Sukirno, Sadono. 2010. Mikro Ekonomi Teori Pengantar. Jakarta: PT. Rajagrafindo Persada. 